\title{
Storage Quality Characteristic of Two Minikiwi Fruit (Actinidia arguta (Siebold \& Zucc.) Planch. ex Miq.) Cultivars: 'Ananasnaya' and 'Bingo'-A New One Selected in Poland
}

\author{
Ewa Szpadzik ${ }^{1, *}$, Ewa Zaraś-Januszkiewicz ${ }^{2}$ and Tomasz Krupa ${ }^{1(D)}$ \\ 1 Department of Pomology and Horticulture Economics, Institute of Horticultural Sciences, Warsaw University \\ of Life Sciences (SGGW-WULS), 159C Nowoursynowska Street, 02-787 Warsaw, Poland; \\ tomasz_krupa@sggw.edu.pl \\ 2 Department of Environment Protection and Dendrology, Institute of Horticultural Sciences, \\ Warsaw University of Life Sciences (SGGW-WULS), 159C Nowoursynowska Street, 02-787 Warsaw, Poland; \\ ewa_zaras_januszkiewicz@sggw.edu.pl \\ * Correspondence: ewa_szpadzik@sggw.edu.pl; Tel.: +48-22-593-21-04
}

\section{check for}

updates

Citation: Szpadzik, E.; Zaraś-Januszkiewicz, E.; Krupa, T. Storage Quality Characteristic of Two Minikiwi Fruit (Actinidia arguta (Siebold \& Zucc.) Planch. ex Miq.) Cultivars: 'Ananasnaya' and 'Bingo'-A New One Selected in Poland. Agronomy 2021, 11, 134. https://doi.org/10.3390/ agronomy11010134

Received: 26 November 2020 Accepted: 8 January 2021 Published: 12 January 2021

Publisher's Note: MDPI stays neutral with regard to jurisdictional clai$\mathrm{ms}$ in published maps and institutional affiliations.

Copyright: (C) 2021 by the authors. Licensee MDPI, Basel, Switzerland. This article is an open access article distributed under the terms and conditions of the Creative Commons Attribution (CC BY) license (https:// creativecommons.org/licenses/by/ $4.0 /)$.

\begin{abstract}
The consumer acceptability of the fruit is very important aspect of distribution. Consumers expect high-quality fruit with high pro-health values. The intention of the research was to assess the quality of hardy kiwi fruit changes during storage in order to provide consumers with high-quality fruit and nutraceutical content. A particular challenge was to assess the storage capacity of the new Polish variety 'Bingo'PBR. This is a protected Plant Breeder's Right (PBR) cultivar in accordance with the Union Internationale pour la Protection des Obtentions Vegetates (UPOV). The storage quality of the fruit of the 'Bingo' cultivar was assessed in contrast to the fruit of the 'Ananasnaya' cultivar, the basic minikiwi cultivar. The experiment assessed the effect of the fruit ripeness phase during harvest ( ${ }^{\circ}$ Brix -7.7 and 9.0 ) and the effect of the storage conditions, i.e., normal atmosphere cold store $\left(0.1 \% \mathrm{CO}_{2}: 21 \% \mathrm{O}_{2}\right)$ versus controlled atmosphere $\left(1.5 \% \mathrm{CO}_{2}: 1.5 \% \mathrm{O}_{2}\right)$. In the fruit evaluation, the focus was concentrated on changes in the basic color of the peel, firmness, soluble solids content, acidity, as well as the main health-promoting attributes, i.e., antioxidant activity, vitamin $\mathrm{C}$ content and total polyphenols. In the experiment, it was found the fruits of 'Ananasnaya' variety were almost $40 \%$ harder than the fruits of 'Bingo' ${ }^{\text {PBR }}$ variety. The CA technology $\left(1.5 \% \mathrm{CO}_{2}: 1.5 \% \mathrm{O}_{2}\right)$ allows for the acceptable firmness of the fruit for up to 56 days of storage. The earlier harvest with an extract content of $7.0-7.5^{\circ}$ Brix also promotes higher fruit firmness. Fruits stored in a normal atmosphere cold store ripen faster and are fully ripe after 28 days. 'Bingo' ${ }^{\text {PBR }}$ variety is characterized by fruits with a higher ascorbic acid content than the fruits of 'Ananasnaya' variety. The vitamin $C$ content in fruits increases up to 28 days, regardless of the conditions in which they are stored. The content of polyphenols does not change significantly during storage, which reflects the higher stability of these compounds in fruits.
\end{abstract}

Keywords: Actinidia arguta; minikiwi; fruit quality; storage; antioxidants; firmness; total soluble solids

\section{Introduction}

The natural habitat of the species Actinidia arguta ((Sieb. \& Zucc.) Planch ex Miq) is the Asian continent. However most of the world-famous hardy kiwi varieties are grown on plantations located in New Zealand, the USA, Japan, Chile and many European countries [1]. In recent years hardy kiwi, popularly known in Europe as minikiwi, has been gaining economic importance and because due to its high resistance to frost it can be cultivated in Poland and in the most European countries [2].

The new polish cultivar of hardy kiwifruit 'Bingo'PBR (A. purpurea 'Purpurna Sadova' $\times A$. arguta) was obtained in the breeding programme conducted at Warsaw University of Life Sciences (WULS-SGGW, Warsaw, Poland). It has dominant characteristics of A. arguta, 
and its fruit differs from other cultivars on the market, mainly in its intense reddish-pink blush and a pineapple-like flavor. The fruit is cylindrical and clearly flattened at the sides. They reach a good size and an average mass of $8 \mathrm{~g}$ (to about $14 \mathrm{~g}$ ). The fruiting potential of 'Bingo' ${ }^{\text {PBR }}$ is lower than that of the popular 'Ananasnaya' cultivar [3].

Actinidia fruits from wild plants have been harvested for hundreds of years and often used also in natural medicine [4]. They contain substantial amounts of vitamin C that often significantly exceed those of other fruits or vegetables [5,6]. They are often referred as "healthy fruits" because, in addition to vitamin C, they contain large amounts of such compounds as polyphenolic acids, flavonoids, carotenoids, chlorophylls and anthocyanins [7]. They are rich in minerals: $\mathrm{K}, \mathrm{Fe}, \mathrm{Zn}, \mathrm{Cu}$ and $\mathrm{Mg}$, as well as vitamins: PP, $\mathrm{A}, \mathrm{B}_{1}$ and $\mathrm{B}_{2}[8,9]$.

Kiwi (A. deliociosa), and especially the fruits of cultivar 'Hayward', can be stored in common cold storage for as long as up to 6 months [10]. However, as shown by previous studies [11], the maximum period of storage in the same conditions for minikiwi fruits is only approx. 3-5 weeks. The development of the crop of this species is inextricably related to the design of appropriate storage technology for hardy kiwifruit, which will extend the availability of fresh fruits, and also allow the export of fruit to remote parts of the world. Storage conditions, adequately chosen for the given species, determine the storage ability of fruits [12-14] This applies to the storage temperature as well as to the relative humidity and gas composition in the cold storage chamber. Decreasing of the respiration process and the synthesis of ethylene positively contributes to the inhibition of other processes associated with fruit ripening, i.e., starch hydrolysis, chlorophyll degradation or fruit softening [15-17]. A major problem during storage time of hardy kiwifruits is their rapid softening after harvest [18-20]. Physiological maturity of fruits at harvest has a decisive effect on the rate of their softening during storage [21,22]. The minikiwi is a climacteric fruit and that is why the endogenous ethylene, produced even in small amounts, activates the exo-polygalacturonase, endo-polygalacturonase, pectin esterase and endo-1,4- $\beta$-D-glucanase enzymes contributing to firmness reduction [23]. The inhibition of this process by reducing synthesis of ethylene under low oxygen conditions or using 1-MCP can significantly contribute to extend the storage ability of fruits [24,25]. Therefore, the aim of these studies was to investigate changes in the physicochemical characteristics occurring in the minikiwi harvested in the different phases of physiological maturity and stored under normal versus of low oxygen conditions. Changes in the quality of the fruit of 'Bingo' - a new Polish cultivar-and 'Ananasnaya' — a standard cultivar commonly grown all over the world-have been described in the research results. The aim of the experiment was to show that the storage quality of 'Bingo' cultivar is better or at least as good as 'Ananasnaya'. Additionally this research allowed us to determine the appropriate method of handling the fruit, the aim of which is to provide consumers with high-quality fruits and nutraceutical content.

\section{Materials and Methods}

\subsection{Outline of the Experiment}

Studies were carried out on the two hardy kiwifruit cultivars-'Ananasnaya', and 'Bingo'PBR ${ }^{\text {PB }}$ Hardy kiwifruits were manually harvested to plastic highvented containers from the experimental field of the Department of Pomology and Horticultural Economics, Warsaw University of Life Sciences (WULS-SGGW), located in Warsaw, central Poland $\left(52.259^{\circ} \mathrm{N}, 21.020^{\circ} \mathrm{E}\right)$. 'Ananasnaya' (A. arguta) is the basic cultivar grown in the USA and is the most widely grown of minikiwi fruit in the world [26]. 'Bingo'PBR is a new cultivar $(A$. arguta $\times$ A. purpurea) created in the breeding programme at WULS, denoted in previous publications as 'D $14^{\prime}[3,11]$. Fruits of both cultivars, selected for uniform size and absence of visible defects, were harvested at two soluble solid contents (SSC)—defined in this text as harvest A and B. Fruits were picked at SSC of $7-8^{\circ}$ Brix (harvest A) and at SSC of $9-10^{\circ}$ Brix (harvest $B$ ). These values may roughly correspond to recommendation from USA [27] and Poland [28]. Immediately after harvest (A and B) fruits were transported to 
the experimental storage of the Department of Pomology and Horticultural Economics and stored in the experimental cold chamber ( $1 \mathrm{~m}^{3}$ capacity). The containers were equipped with an automatic system Oxystat 200 (David Bishoop Ltd., city, The Netherlands), providing continuous monitoring $\mathrm{CO}_{2}$ and $\mathrm{O}_{2}$ levels. Fruits harvested at term $\mathrm{A}$ and $\mathrm{B}$ were stored under refrigerated conditions $\left(1^{\circ} \mathrm{C}\right)$ at $90 \%$ relative air humidity either in normal atmosphere (NA: $0.1 \% \mathrm{CO}_{2}: 21 \% \mathrm{O}_{2}$ ) or in controlled atmosphere (CA) with a low oxygen concentration $\left(1.5 \% \mathrm{CO}_{2}: 1.5 \% \mathrm{O}_{2}\right)$ in a storage chamber. The stored fruit analyses were conducted 5 times, i.e., directly after harvest and at fourteen days intervals during storage up to 56 days of storage. The experiment was replicated three times, each on $0.5 \mathrm{~kg}$ of fruit (approx. 70-80 fruits). To evaluate peel color change and mass loss during the storage additional fruits (30 fruits per replicate) were used and always the measurements were made on the same fruit. Physicochemical analyses were done on fresh fruits. For analyses of bioactive compounds and antioxidant qualities, fruits were frozen in liquid nitrogen (quick freezing) and stored at $-80^{\circ} \mathrm{C}$ in preparation for the analysis.

\subsection{Analytical Methods}

All reagents were of analytical purity gradients or HPLC grade purchased from Sigma-Aldrich (Poznań, Poland) or Merck (Warsaw, Poland). The fruit firmness (FF) was determined as a value of the force necessary for penetration the fruit by $4.5 \mathrm{~mm}$ diameter punch probe. FF was determined on 20 fruits in 3 replications using Instron 5542 penetrometer (Instron, High Wycombe, UK). Each fruit was subjected two times (on opposite side), with compression speed $240 \mathrm{~mm}^{-1}$ during penetration to $5 \mathrm{~mm}$ depth. FF was expressed in Newton (N).

The soluble solid content (SSC) was determined refractometrically, according to the Polish Standard PN-EN 12143:2000 [29] (developed by Polish Committee of Standardization) in the juice squeezed out from 20 fruits. A PR-32 alpha digital refractometer (Atago, Tokyo, Japan) was used to assess SSC in juice, at $20^{\circ} \mathrm{C}$ temperature. Results were expressed in ${ }^{\circ}$ Brix. The titratable acidity (TA) was determined according to the Polish Standard PN-EN 12147:2000 [30]. TA was measured in water extract from an average sample of 20 minced fruits by titrating with $0.1 \mathrm{~N}$ sodium hydroxide $(\mathrm{NaOH})$ to the endpoint of pH 8.1, using a TitroLine 5000 system (Si Analytics, Mainz, Germany). The results were expressed by the percentage of anhydrous citric acid.

Colour was measured in the center of the flat surface of 30 fruits using a Minolta CM501i spectrophotometer (Minolta, Tokyo, Japan) equipped with an $5 \mathrm{~mm}$ measuring head and observer $10^{\circ}$ and illuminant D65. The meter was calibrated using the manufacturer's standard white plate. Colour changes were quantified in the $L^{*}, a^{*}$ and $b^{*}$ color space. Hue angle $\left[\left(h \circ=\tan ^{-1}\left(b^{*} / a^{*}\right)+180^{\circ}\right)\right.$ when $a^{*}<0$ and $\left.b^{*}>0\right]$ and chroma values $\left[C=\left(a^{*} 2+\right.\right.$ $\left.b^{*} 2\right) 1 / 2$ ] were calculated from $a^{*}$ and $b^{*}$ values. Hue angel values refer to a colour wheel. Red, yellow, green and blue colours were at an angle of $0^{\circ}, 60^{\circ}, 120^{\circ}$ and $240^{\circ}$, respectively. Chroma describes the vividness or dullness of fruit colour and also is known as a colour saturation.

Mass loss was measured in three replicates of ten fruits per treatment. Fruits were weighed at the beginning of the experiment and at various times during the course of the storage period, and the results were expressed as the percentage loss of initial mass.

Determination of vitamin C content (ascorbic acid content-AAC) was performed according to the HPLC method of Krupa et al. [11]. Ascorbic acid was extracted from a $50 \mathrm{~g}$ sample of fruit with the mixture of 3\% (w/v) metaphosphoric $(100 \mathrm{~mL})$. Identification and quantitative analysis of AAC were performed using a series 200 HPLC system (Perkin Elmer, Krakow, Poland) equipped with a diode array detector (UV-DAD), using a Spheri-5 RP-18 column $(5 \mu \mathrm{m}, 220 \mathrm{~mm} \times 4.6 \mathrm{~mm}$, Brownlee Columns, Perkin Elmer, Krakow, Poland) at $1.0 \mathrm{~mL} / \mathrm{min}$ flow-rate and detection at $245 \mathrm{~nm}$. The mobile phase was a $0.1 \%$ meta-phosphoric acid. AAC was identified on the basis of a standard and expressed in $\mathrm{mg} / 100 \mathrm{~g}$ FW. The total phenolic content (TPC) was determined by the spectrophotometric method [31], using the Folin-Ciocalteu reagent. The absorbance of the 
solution was measured using a Marcel 330S PRO spectrophotometer (Marcel, Zielonka, Poland) at the wavelength $\lambda=700 \mathrm{~nm}$. Presented results were recalculated into gallic acid. The antioxidant activity (AA) was determined according to the method by Saint Criq de Gaulejac et al. [32] based on the reduction of free radicals obtained from DPPH (1,1-diphenyl-2-picrylhydrazine, Sigma-Aldrich, Poznan, Poland). The AA was calculated on the basis of absorbance measurements for the proper sample (fruit extract $\left.+\mathrm{DPPH}^{+}\right)$performed after $20 \mathrm{~min}$ at $\lambda=517 \mathrm{~nm}$ in relation to the control sample $\left(\mathrm{H}_{2} \mathrm{O}+\right.$ $\mathrm{DPPH}^{+}$). The results were expressed in mg of ascorbic acid equivalent (AAE) per $\mathrm{g}$ of FW.

\subsection{Statistical Analysis}

The results were analysed statistically in the Statistica 12.5 program (StatSoft Polska, Krakow, Poland) using the three-way analysis of variance. For the clarity of the results, they are presented in tables in terms of two-way interaction: separately for the degree of maturity (harvest maturity $\times$ period of storage, averaging the effect of storage conditions) and separately for the storage technology (storage conditions $\times$ period of storage, averaging the effect of the degree of maturity). A Tukey test was used for evaluation of the significance of differences between the means, accepting the significance level as $5 \%$.

\section{Results}

At harvest, it was found that the FF of both cultivars significantly differed. The fruits of 'Ananasnaya' were characterized by firmness of approx. $50 \mathrm{~N}$, while the 'Bingo'PBR approx. 35 N. 14 days after harvest a significant reduction in the FF was found, to an average level of 17.9 and $13.9 \mathrm{~N}$, for 'Ananasnaya' and 'Bingo' ${ }^{\text {PBR }}$ respectively. The conditions of the CA used in the experiment had a positive impact on the firmness of minikiwi fruits. The 'Bingo'PBR fruits were significantly firmer until the 56th day, and 'Ananasnaya' fruits until the 42nd day, if they were stored in CA, not in NA (Table 1).

Table 1. Changes of firmness $[\mathrm{N}]$ measured in 'Ananasnaya' and 'Bingo' $\mathrm{PBR}$ minikiwi fruit in postharvest period.

\begin{tabular}{|c|c|c|c|c|c|}
\hline \multirow{2}{*}{ Variable } & \multicolumn{5}{|c|}{ Time of Storage (Days) } \\
\hline & 0 & 14 & 28 & 42 & 56 \\
\hline & \multicolumn{5}{|c|}{ Ananasnaya } \\
\hline $\mathrm{CA}^{1}$ & $49.9 \pm 4.13^{\mathrm{A} \mathrm{d}}$ & $24.7 \pm 7.16^{\mathrm{B} \mathrm{bc}}$ & $15.1 \pm 3.05^{\mathrm{B} \mathrm{b}}$ & $6.8 \pm 0.80^{\mathrm{B} \mathrm{a}}$ & $4.4 \pm 0.83^{\mathrm{A} \mathrm{a}}$ \\
\hline NA & $49.9 \pm 4.13^{\mathrm{A} \mathrm{d}}$ & $11.1 \pm 2.51^{\mathrm{Ac}}$ & $8.0 \pm 1.58^{\mathrm{A} \mathrm{b}}$ & $3.9 \pm 0.42^{\mathrm{A} \mathrm{a}}$ & $3.4 \pm 0.57^{\mathrm{A} \mathrm{a}}$ \\
\hline Hrv A & $52.6 \pm 3.64^{\mathrm{Bd}}$ & $22.6 \pm 9.26^{\mathrm{Bc}}$ & $12.8 \pm 4.33^{\mathrm{B} \mathrm{b}}$ & $5.6 \pm 1.52 \mathrm{~A} \mathrm{a}$ & $4.5 \pm 0.66^{\mathrm{A} \mathrm{a}}$ \\
\hline Hrv B & $47.3 \pm 2.61^{\mathrm{A} c}$ & $13.3 \pm 4.60 \mathrm{~A} \mathrm{bc}$ & $10.3 \pm 3.88 \mathrm{~A} \mathrm{~b}$ & $5.2 \pm 1.65 \mathrm{~A} \mathrm{a}$ & $3.2 \pm 0.40^{\mathrm{A} \mathrm{a}}$ \\
\hline & \multicolumn{5}{|c|}{ Bingo $^{\text {PBR }}$} \\
\hline CA & $34.3 \pm 2.99 \mathrm{~A} \mathrm{~d}$ & $18.6 \pm 1.83^{\mathrm{B} \mathrm{c}}$ & $11.8 \pm 1.53^{\mathrm{B} \mathrm{b}}$ & $5.7 \pm 1.47^{\mathrm{B} \mathrm{a}}$ & $4.4 \pm 0.30^{\mathrm{B} \mathrm{a}}$ \\
\hline NA & $34.3 \pm 2.99 \mathrm{~A} \mathrm{~d}$ & $9.2 \pm 1.83 \mathrm{Ac}$ & $4.5 \pm 0.74 \mathrm{~A} \mathrm{~b}$ & $2.6 \pm 0.54 \mathrm{~A} \mathrm{a}$ & $2.1 \pm 0.36^{\mathrm{A} \mathrm{a}}$ \\
\hline Hrv A & $37.1 \pm 1.61^{\mathrm{B} \mathrm{e}}$ & $15.6 \pm 4.58^{\mathrm{B} \mathrm{d}}$ & $9.1 \pm 3.87^{\mathrm{B} \mathrm{c}}$ & $5.4 \pm 2.07^{\mathrm{B} \mathrm{b}}$ & $3.3 \pm 1.02 \mathrm{~A} \mathrm{a}$ \\
\hline Hrv B & $31.6 \pm 0.39 \mathrm{~A} \mathrm{~d}$ & $12.2 \pm 4.84^{\mathrm{Ac}}$ & $7.3 \pm 3.60^{\mathrm{A} \mathrm{b}}$ & $3.2 \pm 1.17 \mathrm{~A} \mathrm{a}$ & $3.2 \pm 1.35^{\mathrm{A} \mathrm{a}}$ \\
\hline
\end{tabular}

${ }^{1}$ CA—controlled atmosphere; NA-normal atmosphere cold store; Hrv A—harvest A; Hrv B-harvest B; \pm -standard deviation; different superscript letters are assigned to statistically significant differences when comparing (capital letter): storage conditions (average for stage maturity) or harvest maturity (average for storage conditions) and (lower case): period of storage; the cultivars were not compared with each other.

The experiments proved that not only storage conditions, but also state of physiological maturity of the fruits determines their firmness. Hardy kiwifruits of 'Ananasnaya' harvested when the soluble solids content (SSC) was $7.6^{\circ}$ Brix were distinguished by a

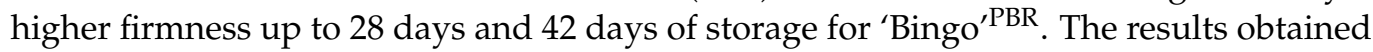
indicate a slower softening of fruits harvested in the first period (harvest A).

The results obtained show that during storage there is an increase of the SSC in hardy kiwifruits. It should be noted that the rapid increase in the SSC was observed after 14 days of storage (Table 2). Faster starch hydrolysis to monosaccharaides and the related growth of extract content occurred in fruits stored in the NA than in a CA. The 'Ananasnaya' 
fruits turned out to be "sweeter" because their maximum value of SSC after storage was $15.8^{\circ}$ Brix, while the 'Bingo ${ }^{\prime}{ }^{\mathrm{PBR}}-13.5^{\circ} \mathrm{Brix}$. In NA conditions respiration process takes place more dynamically, leading to the rapid consumption of substrates. The result of this process may be a lower SSC in 'Bingo' ${ }^{\prime P B R}$ fruits stored in NA than in CA after 56 days, as observed in the experiment. Fruits of two cultivars derived from the harvest $B$, during the testing period were characterized by a higher value of this parameter. Presumably, this was associated with a longer period of berry ripening on the vine, and the related increase in the content of assimilates in the cells of the fruit.

Table 2. Changes of total solids soluble content [ ${ }^{\circ}$ Brix] measured in 'Ananasnaya' and 'Bingo'PBR minikiwi fruit in postharvest period.

\begin{tabular}{|c|c|c|c|c|c|}
\hline \multirow{2}{*}{ Variable } & \multicolumn{5}{|c|}{ Time of Storage (Days) } \\
\hline & 0 & 14 & 28 & & 56 \\
\hline & \multicolumn{5}{|c|}{ Ananasnaya } \\
\hline $\mathrm{CA}^{1}$ & $8.3 \pm 0.71 \mathrm{~A} \mathrm{a}$ & $12.6 \pm 0.55^{\mathrm{Ab}}$ & $14.4 \pm 1.08 \mathrm{Ac}$ & $14.5 \pm 0.41 \mathrm{Ac}$ & $15.6 \pm 0.67^{B ~ d}$ \\
\hline NA & $8.3 \pm 0.71 \mathrm{~A} \mathrm{a}$ & $13.1 \pm 0.15^{\mathrm{B} \mathrm{b}}$ & $15.1 \pm 0.37^{\mathrm{B} \mathrm{c}}$ & $15.1 \pm 0.19^{\mathrm{B} \mathrm{c}}$ & $15.1 \pm 0.42 \mathrm{~A} \mathrm{a}$ \\
\hline Hrv A & $7.7 \pm 0.12 \mathrm{~A} \mathrm{a}$ & $12.6 \pm 0.53 \mathrm{Ab}$ & $14.1 \pm 0.78^{\mathrm{A} \mathrm{c}}$ & $14.7 \pm 0.44 \mathrm{~A} \mathrm{~d}$ & $14.9 \pm 0.28 \mathrm{Ad}$ \\
\hline \multirow[t]{2}{*}{ Hrv B } & $9.0 \pm 0.25 \mathrm{~B} \mathrm{a}$ & $13.1 \pm 0.14^{\mathrm{B} \mathrm{b}}$ & $15.4 \pm 0.20^{\mathrm{B} \mathrm{d}}$ & $14.9 \pm 0.38 \mathrm{Ac}$ & $15.8 \pm 0.50 \mathrm{Bd}$ \\
\hline & \multicolumn{5}{|c|}{ Bingo $^{\text {PBR }}$} \\
\hline CA & $8.3 \pm 0.72 \mathrm{~A} \mathrm{a}$ & $10.7 \pm 0.30 \mathrm{Ab}$ & $11.8 \pm 0.35 \mathrm{~A} \mathrm{c}$ & $12.9 \pm 0.27 \mathrm{~A} \mathrm{~d}$ & $13.5 \pm 0.22 \mathrm{~A} \mathrm{e}$ \\
\hline NA & $8.3 \pm 0.72 \mathrm{~A} \mathrm{a}$ & $11.5 \pm 0.63^{\mathrm{B} \mathrm{b}}$ & $12.8 \pm 0.60^{\mathrm{B} \mathrm{c}}$ & $13.8 \pm 0.25^{\mathrm{B} \mathrm{e}}$ & $13.3 \pm 0.28^{\mathrm{A} \mathrm{a}}$ \\
\hline Hrv A & $7.6 \pm 0.08 \mathrm{~A} \mathrm{a}$ & $10.7 \pm 0.29 \mathrm{Ab}$ & $12.1 \pm 0.41 \mathrm{Ac}$ & $13.3 \pm 0.60 \mathrm{~A} \mathrm{~d}$ & $13.2 \pm 0.25^{\mathrm{Ad}}$ \\
\hline Hrv B & $9.0 \pm 0.22 \mathrm{~B} \mathrm{a}$ & $11.5 \pm 0.63^{\mathrm{B} \mathrm{b}}$ & $12.6 \pm 0.89 \mathrm{~B} \mathrm{C}$ & $13.4 \pm 0.33^{\mathrm{B} \mathrm{d}}$ & $13.5 \pm 0.20^{\mathrm{B} \mathrm{d}}$ \\
\hline
\end{tabular}

${ }^{1}$ CA—controlled atmosphere; NA-normal atmosphere cold store; Hrv A—harvest A; Hrv B—harvest B; \pm —standard deviation; different superscript letters are assigned to statistically significant differences when comparing (capital letter): storage conditions (average for stage maturity) or harvest maturity (average for storage conditions) and (lower case): period of storage; the cultivars were not compared with each other.

Own studies confirm that TA decreases significantly during storage (Table 3). Generally, higher TA was found in fruits of harvest A and stored in the CA chamber. Decrease in acidity is associated with respiration occurring in fruits. Therefore, higher TA found in fruits stored in CA (after 42 and 56 days) was the result of slower ripening of the fruits caused by the reduced concentration of $\mathrm{O}_{2}$ and by $\mathrm{CO}_{2}$ increase.

Table 3. Changes of titratable acidity [\% citric acid] measured in 'Ananasnaya' and 'Bingo'PBR minikiwi fruit in postharvest period.

\begin{tabular}{|c|c|c|c|c|c|}
\hline \multirow{2}{*}{ Variable } & \multicolumn{5}{|c|}{ Time of Storage (Days) } \\
\hline & 0 & 14 & 28 & 42 & 56 \\
\hline & \multicolumn{5}{|c|}{ Ananasnaya } \\
\hline $\mathrm{CA}^{1}$ & $1.08 \pm 0.04 \mathrm{~A} \mathrm{~d}$ & $1.04 \pm 0.03 \mathrm{~A} \mathrm{~d}$ & $0.97 \pm 0.06^{\mathrm{Ac}}$ & $0.84 \pm 0.03^{\mathrm{B} \mathrm{b}}$ & $0.72 \pm 0.06^{\mathrm{B} \mathrm{a}}$ \\
\hline NA & $1.08 \pm 0.04 \mathrm{~A} \mathrm{~d}$ & $1.02 \pm 0.03 \mathrm{~A} \mathrm{~d}$ & $0.93 \pm 0.06^{\mathrm{Ac}}$ & $0.69 \pm 0.04 \mathrm{Ab}$ & $0.54 \pm 0.03^{\mathrm{A} \mathrm{a}}$ \\
\hline Hrv A & $1.09 \pm 0.04 \mathrm{~A} \mathrm{~d}$ & $1.05 \pm 0.03 \mathrm{~A} \mathrm{~d}$ & $0.98 \pm 0.05^{\mathrm{Bc}}$ & $0.78 \pm 0.06^{\mathrm{A} \mathrm{b}}$ & $0.67 \pm 0.10^{\mathrm{Ba}}$ \\
\hline \multirow[t]{2}{*}{ Hrv B } & $1.07 \pm 0.04^{\mathrm{Ad}}$ & $1.01 \pm 0.02^{\mathrm{A} \mathrm{d}}$ & $0.91 \pm 0.06^{\mathrm{Ac}}$ & $0.75 \pm 0.10^{\mathrm{Ab}}$ & $0.57 \pm 0.08^{\mathrm{A} \mathrm{a}}$ \\
\hline & \multicolumn{5}{|c|}{ Bingo $^{\text {PBR }}$} \\
\hline CA & $1.13 \pm 0.02 \mathrm{~A} \mathrm{e}$ & $1.09 \pm 0.01 \mathrm{~A} \mathrm{~d}$ & $1.00 \pm 0.02^{\mathrm{B} \mathrm{C}}$ & $0.87 \pm 0.03^{\mathrm{B} \mathrm{b}}$ & $0.82 \pm 0.07^{\mathrm{B} \mathrm{a}}$ \\
\hline NA & $1.13 \pm 0.02 \mathrm{~A} \mathrm{e}$ & $1.08 \pm 0.02 \mathrm{~A} \mathrm{~d}$ & $0.97 \pm 0.05^{\mathrm{Ac}}$ & $0.81 \pm 0.07 \mathrm{~A} \mathrm{~b}$ & $0.59 \pm 0.08 \mathrm{~A} \mathrm{a}$ \\
\hline Hrv A & $1.14 \pm 0.01 \mathrm{~A} \mathrm{e}$ & $1.10 \pm 0.01 \mathrm{~B} \mathrm{~d}$ & $1.01 \pm 0.02^{\mathrm{B} \mathrm{c}}$ & $0.87 \pm 0.02 \mathrm{~B} \mathrm{~b}$ & $0.77 \pm 0.01^{\mathrm{B} \mathrm{a}}$ \\
\hline Hrv B & $1.12 \pm 0.02 \mathrm{~A} \mathrm{e}$ & $1.07 \pm 0.01 \mathrm{~A} \mathrm{~d}$ & $0.96 \pm 0.03 \mathrm{Ac}$ & $0.81 \pm 0.07 \mathrm{~A} \mathrm{~b}$ & $0.63 \pm 0.12^{\mathrm{A} \mathrm{a}}$ \\
\hline
\end{tabular}

${ }^{1}$ CA—controlled atmosphere; NA—normal atmosphere cold store; Hrv A—harvest A; Hrv B—harvest B; \pm —standard deviation; different superscript letters are assigned to statistically significant differences when comparing (capital letter): storage conditions (average for stage maturity) or harvest maturity (average for storage conditions) and (lower case): period of storage; the cultivars were not compared with each other. 
As a result of transpiration and a respiration process, the fruits lost after storage almost $2.5 \%$ of their initial mass (Table 4 ). It is surprising that higher losses were recorded in fruits harvested in the first period of harvest (harvest A) than in the second (harvest B). Fruit stored in a CA, as expected, showed, less weight loss, regardless of the length of the storage period.

Table 4. Changes of fruit mass loss [\%] measured in 'Ananasnaya' and 'Bingo' ${ }^{\text {PBR }}$ minikiwi friuit in postharvest period.

\begin{tabular}{|c|c|c|c|c|c|}
\hline \multirow{2}{*}{ Variable } & \multicolumn{5}{|c|}{ Time of Storage (Days) } \\
\hline & 0 & 14 & 28 & 42 & 56 \\
\hline \multicolumn{6}{|c|}{ Ananasnaya } \\
\hline $\mathrm{CA}^{1}$ & - & $0.53 \pm 0.14^{\mathrm{A} \mathrm{a}}$ & $0.82 \pm 0.19 \mathrm{Ab}$ & $1.15 \pm 0.22 \mathrm{Ac}$ & $1.63 \pm 0.43 \mathrm{~A} \mathrm{~d}$ \\
\hline NA & - & $0.96 \pm 0.42^{\mathrm{B} \mathrm{a}}$ & $1.45 \pm 0.65^{\mathrm{Bb}}$ & $1.89 \pm 0.58^{\mathrm{Bc}}$ & $2.25 \pm 0.75^{\mathrm{B} \mathrm{d}}$ \\
\hline Hrv A & - & $0.99 \pm 0.41 \mathrm{~B} \mathrm{a}$ & $1.51 \pm 0.61^{\mathrm{Bb}}$ & $1.87 \pm 0.61^{\mathrm{Bc}}$ & $2.54 \pm 0.52^{B ~ d}$ \\
\hline Hrv B & - & $0.51 \pm 0.08^{\mathrm{A} \mathrm{a}}$ & $0.78 \pm 0.13 \mathrm{Ab}$ & $1.17 \pm 0.20^{\mathrm{Ac}}$ & $1.41 \pm 0.18 \mathrm{~A} \mathrm{~d}$ \\
\hline \multicolumn{6}{|c|}{ Bingo $^{\text {PBR }}$} \\
\hline CA & - & $0.59 \pm 0.17 \mathrm{~A} \mathrm{a}$ & $0.98 \pm 0.28 \mathrm{Ab}$ & $1.34 \pm 0.23^{\mathrm{Ac}}$ & $1.68 \pm 0.22 \mathrm{~A} \mathrm{~d}$ \\
\hline NA & - & $1.08 \pm 0.13^{\mathrm{B} \mathrm{a}}$ & $1.81 \pm 0.21 \mathrm{~B} \mathrm{~b}$ & $1.98 \pm 0.24 \mathrm{~B} \mathrm{c}$ & $2.45 \pm 0.29 \mathrm{~B} \mathrm{~d}$ \\
\hline Hrv A & - & $0.96 \pm 0.21 \mathrm{~B} \mathrm{a}$ & $1.60 \pm 0.36^{\mathrm{Bb}}$ & $1.83 \pm 0.32^{\mathrm{Bc}}$ & $2.24 \pm 0.40^{\mathrm{B} \mathrm{d}}$ \\
\hline Hrv B & - & $0.69 \pm 0.29 \mathrm{~A} \mathrm{a}$ & $1.15 \pm 0.49 \mathrm{Ab}$ & $1.47 \pm 0.39 \mathrm{~A} \mathrm{c}$ & $1.85 \pm 0.45^{\mathrm{A} \mathrm{d}}$ \\
\hline
\end{tabular}

${ }^{1}$ CA—controlled atmosphere; NA—normal atmosphere cold store; Hrv A—harvest A; Hrv B—harvest B; \pm —standard deviation; different superscript letters are assigned to statistically significant differences when comparing (capital letter): storage conditions (average for stage maturity) or harvest maturity (average for storage conditions) and (lower case): period of storage; the cultivars were not compared with each other.

All fruits of both tested cultivars differed in the color of the skin. Berries of 'Ananasnaya' variety were characterized by a much greener basic color of the surface, which was expressed by a lower value of the ' $a$ ' parameter (on average -6.84 , immediately after harvest) compared to 'Bingo ${ }^{\text {PBR }}$ (on average -5.67 , immediately after harvest) (Table 5). This is also confirmed by the values of the 'hue angel' parameter, which indicate the dominant green skin of 'Ananasnaya' variety (Table 6). The results obtained in the experiment show that the fruits of 'Ananasnaya' lose their green color faster. This process was particularly intense in the fruit stored in the NA, compared to the CA, in which the fruit also became less and less green, but the change was much milder. The research results indicate that the physiological state of the fruit at the time of harvesting did not determine the color changes expressed by the ' $a$ ' parameter, and the rate of changes was identical, regardless of the date of harvesting the fruit. The values of the 'hue angel' parameter prove that 'Ananasnaya' fruit had an intensely green, even grass-green, basic color of the peel and even after 56 days of storage it was greener than the color of the 'Bingo' ${ }^{\mathrm{PBR}}$ peel immediately after harvest (Table 6). During storage, the hue of the skin color of both cultivars changed towards yellow, although this process was slightly slower in the fruit stored in a CA. As in the case of the ' $a$ ' parameter, the state of ripeness at the time of harvesting the fruit did not significantly change the color of the peel of both tested cultivars. 
Table 5. Changes of skin colour [parameter 'a'] measured in 'Ananasnaya' and 'Bingo'PBR minikiwi in postharvest period.

\begin{tabular}{|c|c|c|c|c|c|}
\hline \multirow{2}{*}{ Variable } & \multicolumn{5}{|c|}{ Time of Storage (Days) } \\
\hline & 0 & 14 & 28 & 42 & 56 \\
\hline $\begin{array}{c}\text { CA }^{1} \\
\text { NA } \\
\text { Hrv A } \\
\text { Hrv B }\end{array}$ & $\begin{array}{l}-6.80 \pm 0.30 \mathrm{Ad} \\
-6.87 \pm 0.31 \mathrm{Ae} \\
-6.73 \pm 0.34 \mathrm{Ae} \\
-6.93 \pm 0.25 \mathrm{Ae}\end{array}$ & $\begin{array}{l}-5.86 \pm 0.34 \mathrm{Ac} \\
-5.62 \pm 0.35 \mathrm{Ad} \\
-5.82 \pm 0.38 \mathrm{Ad} \\
-5.66 \pm 0.35 \mathrm{Ad}\end{array}$ & $\begin{array}{l}\text { Ananasnaya } \\
-5.26 \pm 0.44 \mathrm{Bc} \\
-4.52 \pm 0.42 \mathrm{Ac} \\
-5.13 \pm 0.53 \mathrm{Ac} \\
-4.65 \pm 0.50 \mathrm{Ac}\end{array}$ & $\begin{array}{l}-4.70 \pm 0.42^{\mathrm{Bb}} \\
-3.42 \pm 0.44 \mathrm{~A} \mathrm{~b} \\
-4.23 \pm 0.84 \mathrm{Ab} \\
-3.90 \pm 0.66 \mathrm{Ab}\end{array}$ & $\begin{array}{l}-3.59 \pm 0.34 \mathrm{~B} \mathrm{a} \\
-2.20 \pm 0.28 \mathrm{~A} \mathrm{a} \\
-2.84 \pm 0.79 \mathrm{~A} \mathrm{a} \\
-2.95 \pm 0.72 \mathrm{~A} \mathrm{a}\end{array}$ \\
\hline $\begin{array}{c}\text { CA } \\
\text { NA } \\
\text { Hrv A } \\
\text { Hrv B }\end{array}$ & $\begin{array}{l}-5.70 \pm 0.44 \mathrm{Ac} \\
-5.63 \pm 0.35 \mathrm{~A} \mathrm{~d} \\
-5.78 \pm 0.35 \mathrm{Ac} \\
-5.53 \pm 0.40 \mathrm{Ac}\end{array}$ & $\begin{array}{l}-5.17 \pm 0.37 \mathrm{Ac} \\
-4.78 \pm 0.28 \mathrm{Ac} \\
-5.02 \pm 0.36 \mathrm{Ab} \\
-4.93 \pm 0.39 \mathrm{Ac}\end{array}$ & $\begin{array}{c}\text { Bingo }^{\text {PBR }} \\
-4.67 \pm 0.43^{\mathrm{B} \mathrm{b}} \\
-4.04 \pm 0.36^{\mathrm{A} \mathrm{b}} \\
-4.49 \pm 0.39 \mathrm{~A} \mathrm{~b} \\
-4.22 \pm 0.57^{\mathrm{A} \mathrm{b}}\end{array}$ & $\begin{array}{l}-4.05 \pm 0.29 \mathrm{~B} \mathrm{a} \\
-3.14 \pm 0.32 \mathrm{~A} \mathrm{a} \\
-3.67 \pm 0.57 \mathrm{~A} \mathrm{a} \\
-3.52 \pm 0.51 \mathrm{~A} \mathrm{a}\end{array}$ & $\begin{array}{l}-3.92 \pm 0.30 \mathrm{~B} \mathrm{a} \\
-3.06 \pm 0.30 \mathrm{~A} \mathrm{a} \\
-3.59 \pm 0.51 \mathrm{~A} \mathrm{a} \\
-3.39 \pm 0.48 \mathrm{~A} \mathrm{a}\end{array}$ \\
\hline
\end{tabular}

${ }^{1}$ CA—controlled atmosphere; NA—normal atmosphere cold store; Hrv A—harvest A; Hrv B—harvest B; \pm —standard deviation; different superscript letters are assigned to statistically significant differences when comparing (capital letter): storage conditions (average for stage maturity) or harvest maturity (average for storage conditions) and (lower case): period of storage; the cultivars were not compared with each other.

Table 6. Changes of skin colour [hue angle] measured in 'Ananasnaya' and 'Bingo'PBR minikiwi fruit in postharvest period.

\begin{tabular}{|c|c|c|c|c|c|}
\hline \multirow{2}{*}{ Variable } & \multicolumn{5}{|c|}{ Time of Storage (Days) } \\
\hline & 0 & 14 & 28 & 42 & 56 \\
\hline & \multicolumn{5}{|c|}{ Ananasnaya } \\
\hline $\mathrm{CA}^{1}$ & $118.8 \pm 1.6^{\mathrm{Ac}}$ & $117.8 \pm 1.9^{\mathrm{A} \mathrm{bc}}$ & $117.0 \pm 2.4 \mathrm{~A} \mathrm{bc}$ & $116.1 \pm 1.5^{\mathrm{Bb}}$ & $113.8 \pm 1.2^{\mathrm{B} \mathrm{a}}$ \\
\hline NA & $118.8 \pm 1.7 \mathrm{~A} \mathrm{~d}$ & $117.5 \pm 1.9 \mathrm{Acd}$ & $115.8 \pm 2.3^{\mathrm{Ac}}$ & $113.4 \pm 1.6^{\mathrm{A} \mathrm{b}}$ & $110.0 \pm 1.0^{\mathrm{A} \mathrm{a}}$ \\
\hline Hrv A & $118.7 \pm 1.9^{\mathrm{A} \mathrm{c}}$ & $117.8 \pm 2.1$ А c & $116.8 \pm 2.9^{\mathrm{A} \mathrm{bc}}$ & $115.2 \pm 3.1 \mathrm{~A} \mathrm{~b}$ & $111.9 \pm 2.9^{\mathrm{A} \mathrm{a}}$ \\
\hline Hrv B & $118.9 \pm 1.4^{\mathrm{Ac}}$ & $117.6 \pm 1.9 \mathrm{Ac}$ & $116.0 \pm 2.7^{\mathrm{A} b c}$ & $114.5 \pm 2.4^{\mathrm{Ab}}$ & $112.2 \pm 2.6^{\mathrm{A} \mathrm{a}}$ \\
\hline \multicolumn{6}{|c|}{ Bingo $^{\text {PBR }}$} \\
\hline CA & $106.6 \pm 2.4^{\mathrm{A} \mathrm{b}}$ & $105.4 \pm 2.0 \mathrm{~A} \mathrm{~b}$ & $104.0 \pm 2.3^{\mathrm{B} \mathrm{ab}}$ & $102.3 \pm 1.1^{\mathrm{B} \mathrm{a}}$ & $101.5 \pm 1.1 \mathrm{~B} \mathrm{a}$ \\
\hline NA & $106.5 \pm 1.9 \mathrm{~A} \mathrm{c}$ & $104.7 \pm 1.5^{\mathrm{Ac}}$ & $101.8 \pm 2.0 \mathrm{~A} \mathrm{~b}$ & $99.2 \pm 1.2 \mathrm{~A} \mathrm{ab}$ & $98.5 \pm 0.9 \mathrm{~A} \mathrm{a}$ \\
\hline Hrv A & $106.7 \pm 1.9^{\mathrm{A} \mathrm{b}}$ & $105.1 \pm 2.0^{\mathrm{A} \mathrm{b}}$ & $103.2 \pm 2.1^{\mathrm{A} \mathrm{ab}}$ & $101.0 \pm 2.1 \mathrm{~A} \mathrm{a}$ & $100.2 \pm 1.9^{\mathrm{A} \mathrm{a}}$ \\
\hline Hrv B & $106.4 \pm 2.2^{\mathrm{A} \mathrm{b}}$ & $105.0 \pm 2.1^{\mathrm{A} \mathrm{b}}$ & $102.7 \pm 3.1^{\mathrm{A} \mathrm{ab}}$ & $100.6 \pm 1.9^{\mathrm{A} \mathrm{a}}$ & $99.8 \pm 1.7^{\mathrm{A} \mathrm{a}}$ \\
\hline
\end{tabular}

${ }^{1}$ CA—controlled atmosphere; NA—normal atmosphere cold store; Hrv A—harvest A; Hrv B—harvest B; \pm —standard deviation; different superscript letters are assigned to statistically significant differences when comparing (capital letter): storage conditions (average for stage maturity) or harvest maturity (average for storage conditions) and (lower case): period of storage; the cultivars were not compared with each other.

'Ananasnaya' fruit was characterized by a slightly higher color intensity after harvest than the 'Bingo' ${ }^{\text {PBR }}$ fruit (32.8 and 29.8, respectively). During storage, a decrease in the saturation of the skin color of the fruit was observed (Table 7). This process progressed slightly faster in the peel of the fruit stored in a NA, but this relationship was only observed after 42 days of storage for Ananasnaya 'and 28 for' Bingo $^{\text {PBR }}$. Harvest maturity during fruit harvesting did not imply the nature of changes in the saturation of the basic skin color of both cultivars during storage.

In general we can say that, regardless of storage conditions AAC in fruits increased up to 28th day, then decreased although not always significantly as far as statistics is concerned (Table 8). The results of the studies show that fruits which ripen longer on the vine may contain higher amount of vitamin $C$. 'Bingo' ${ }^{\text {PBR }}$ fruits were characterized by a higher content of vitamin $C$ if harvested at higher soluble solids, which was not observed in the 'Ananasnaya' fruits. 
Table 7. Changes of skin colour [Chroma] measured in 'Ananasnaya' and 'Bingo'PBR minikiwi fruit in postharvest period.

\begin{tabular}{|c|c|c|c|c|c|}
\hline \multirow{2}{*}{ Variable } & \multicolumn{5}{|c|}{ Time of Storage (Days) } \\
\hline & 0 & 14 & 28 & 42 & 56 \\
\hline & \multicolumn{5}{|c|}{ Ananasnaya } \\
\hline $\mathrm{CA}^{1}$ & $32.8 \pm 1.6^{\mathrm{Ac}}$ & $31.0 \pm 1.9 \mathrm{~A} \mathrm{bc}$ & $29.2 \pm 2.4 \mathrm{Abc}$ & $25.9 \pm 1.5^{\mathrm{B} \mathrm{b}}$ & $23.5 \pm 1.2^{\mathrm{B} \mathrm{a}}$ \\
\hline NA & $32.7 \pm 1.7 \mathrm{~A} \mathrm{~d}$ & $31.1 \pm 1.9 \mathrm{~A} \mathrm{~cd}$ & $29.5 \pm 2.3 \mathrm{Ac}$ & $26.4 \pm 1.6^{\mathrm{A} \mathrm{b}}$ & $24.0 \pm 1.0 \mathrm{~A} \mathrm{a}$ \\
\hline Hrv A & $32.8 \pm 1.9 \mathrm{Ac}$ & $31.0 \pm 2.1 \mathrm{Ac}$ & $29.2 \pm 2.9^{\mathrm{A} \mathrm{bc}}$ & $26.1 \pm 3.1 \mathrm{Ab}$ & $23.8 \pm 2.9 \mathrm{~A} \mathrm{a}$ \\
\hline Hrv B & $32.7 \pm 1.4^{\mathrm{Ac}}$ & $31.1 \pm 1.9^{\mathrm{A} \mathrm{c}}$ & $29.5 \pm 2.7^{\mathrm{A} \mathrm{bc}}$ & $26.2 \pm 2.4^{\mathrm{A} \mathrm{b}}$ & $23.8 \pm 2.6 \mathrm{~A} \mathrm{a}$ \\
\hline & \multicolumn{5}{|c|}{ Bingo $^{\text {PBR }}$} \\
\hline CA & $29.8 \pm 2.4^{\mathrm{A} \mathrm{b}}$ & $26.8 \pm 2.0^{\mathrm{A} \mathrm{b}}$ & $25.0 \pm 2.3^{\mathrm{B} \mathrm{a}}$ & $22.2 \pm 1.1^{\mathrm{B} \mathrm{a}}$ & $20.1 \pm 1.1^{\mathrm{B} \mathrm{a}}$ \\
\hline NA & $29.9 \pm 1.9$ А c & $25.9 \pm 1.5^{\mathrm{Ac}}$ & $24.3 \pm 2.0 \mathrm{~A} \mathrm{~b}$ & $21.5 \pm 1.2^{\mathrm{A} \mathrm{a}}$ & $19.3 \pm 0.9^{\mathrm{A} \mathrm{a}}$ \\
\hline Hrv A & $29.8 \pm 1.9 \mathrm{~A} \mathrm{~b}$ & $27.3 \pm 2.0 \mathrm{~A} \mathrm{~b}$ & $25.4 \pm 2.1 \mathrm{~A} \mathrm{ab}$ & $22.4 \pm 2.1^{\mathrm{A} \mathrm{a}}$ & $21.1 \pm 1.9^{\mathrm{A} \mathrm{a}}$ \\
\hline Hrv B & $29.8 \pm 2.2^{\mathrm{A} \mathrm{b}}$ & $25.3 \pm 2.1 \mathrm{~A} \mathrm{~b}$ & $24.0 \pm 3.1^{\mathrm{A} \mathrm{ab}}$ & $21.8 \pm 1.9 \mathrm{~A} \mathrm{a}$ & $18.2 \pm 1.7 \mathrm{~A} \mathrm{a}$ \\
\hline
\end{tabular}

${ }^{1} \mathrm{CA}$-controlled atmosphere; NA—normal atmosphere cold store; Hrv A—harvest A; Hrv B—harvest B; \pm —standard deviation; different superscript letters are assigned to statistically significant differences when comparing (capital letter): storage conditions (average for stage maturity) or harvest maturity (average for storage conditions) and (lower case): period of storage; the cultivars were not compared with each other.

Table 8. Changes of ascorbic acid [mg. $\left.100 \mathrm{~g}^{-1} \mathrm{f} . \mathrm{w}.\right]$ measured in 'Ananasnaya' and 'Bingo'PBR minikiwi fruit in postharvest period.

\begin{tabular}{|c|c|c|c|c|c|}
\hline \multirow{2}{*}{ Variable } & \multicolumn{5}{|c|}{ Time of Storage (Days) } \\
\hline & 0 & 14 & 28 & 42 & 56 \\
\hline & & & Ananasnaya & & \\
\hline $\mathrm{CA}^{1}$ & $73.6 \pm 6.9 \mathrm{~A} \mathrm{ab}$ & $77.2 \pm 3.4^{\mathrm{Ab}}$ & $81.6 \pm 5.6 \mathrm{Ab}$ & $75.0 \pm 6.2^{\mathrm{A} \mathrm{ab}}$ & $63.7 \pm 7.7^{\mathrm{A} \mathrm{a}}$ \\
\hline NA & $73.6 \pm 6.9^{\mathrm{A} \mathrm{a}}$ & $77.5 \pm 6.4^{\mathrm{A} \mathrm{a}}$ & $82.2 \pm 8.9^{\mathrm{A} \mathrm{a}}$ & $78.9 \pm 6.4^{\mathrm{A} \mathrm{a}}$ & $72.4 \pm 6.1^{\mathrm{B} \mathrm{a}}$ \\
\hline Hrv A & $74.4 \pm 7.3^{\mathrm{A} \mathrm{a}}$ & $77.6 \pm 6.1 \mathrm{~A} \mathrm{a}$ & $81.7 \pm 8.5^{\mathrm{A} \mathrm{a}}$ & $80.4 \pm 4.8^{\mathrm{A} \mathrm{a}}$ & $73.1 \pm 7.1^{\mathrm{B} \mathrm{a}}$ \\
\hline \multirow[t]{2}{*}{ Hrv B } & $72.8 \pm 6.3^{\mathrm{A} \mathrm{ab}}$ & $77.1 \pm 4.0^{\mathrm{A} \mathrm{b}}$ & $82.2 \pm 6.2^{\mathrm{A} \mathrm{b}}$ & $73.5 \pm 6.8 \mathrm{~A} \mathrm{~b}$ & $63.1 \pm 5.8^{\mathrm{A} \mathrm{a}}$ \\
\hline & & & Bingo $^{\text {PBR }}$ & & \\
\hline CA & $70.9 \pm 8.9 \mathrm{~A} \mathrm{a}$ & $74.5 \pm 6.2 \mathrm{~A} \mathrm{a}$ & $78.8 \pm 4.2^{\mathrm{A} \mathrm{a}}$ & $75.5 \pm 8.5^{\mathrm{A} \mathrm{a}}$ & $79.8 \pm 5.2^{\mathrm{B} \mathrm{a}}$ \\
\hline NA & $70.9 \pm 8.9^{\mathrm{A} \mathrm{ab}}$ & $77.5 \pm 4.2 \mathrm{~A} \mathrm{~b}$ & $78.9 \pm 9.3 \mathrm{Ab}$ & $80.6 \pm 6.1 \mathrm{Ab}$ & $66.3 \pm 9.3^{\mathrm{A} \mathrm{a}}$ \\
\hline Hrv A & $62.9 \pm 2.2 \mathrm{~A} \mathrm{a}$ & $64.9 \pm 4.8^{\mathrm{A} \mathrm{a}}$ & $67.8 \pm 9.7^{\mathrm{A} \mathrm{a}}$ & $66.4 \pm 9.7 \mathrm{~A} \mathrm{a}$ & $60.4 \pm 6.0 \mathrm{~A} \mathrm{a}$ \\
\hline Hrv B & $79.0 \pm 5.2^{\mathrm{B} \mathrm{a}}$ & $84.1 \pm 5.7 \mathrm{~B} \mathrm{a}$ & $89.9 \pm 9.6^{\mathrm{B} \mathrm{b}}$ & $89.7 \pm 5.2^{\mathrm{B} \mathrm{b}}$ & $85.7 \pm 11.3^{\mathrm{B} \mathrm{b}}$ \\
\hline
\end{tabular}

${ }^{1}$ CA—controlled atmosphere; NA—normal atmosphere cold store; Hrv A-harvest A; Hrv B—harvest B; \pm -standard deviation; different superscript letters are assigned to statistically significant differences when comparing (capital letter): storage conditions (average for stage maturity) or harvest maturity (average for storage conditions) and (lower case): period of storage; the cultivars were not compared with each other.

In general we can say that the total polyphenol content remained at a similar level ('Ananasnaya') or slightly decreased during storage ('Bingo' $\left.{ }^{\text {PBR }}\right)$. In an independently performed experiment, an increase in the TPC was observed up to 28th day of storage ('Ananasnaya'), however, it was not confirmed by statistics. The state of physiological ripeness of fruit at harvest did not determine the TPC (Table 9). Only in the fruits of 'Ananasnaya' the increase in polyphenol content was observed after 14 and 28 days if the fruits originated from the first harvest, but in consecutive dates of analyses the TPC decreased.

The conditions of fruit storage did not imply the AA of the fruit, and the directions of changes in value of this index were similar for both cultivars. Contrary to expectations, 'Bingo, ${ }^{\text {PBR }}$ fruits harvested during the second harvest were characterized by a higher antioxidant activity than the fruits from the first harvest, after the 28th day of maturing in a cold store (Table 10). A similar relationship was not found during the storage of 'Ananasnaya' fruit. The interaction of the rate of changes in AA against the background of storage technology was not clear. The fruit of 'Ananasnaya' stored in NA was characterized by a stable level of activity, while the fruit stored in CA was characterized by higher activity until the 56th day of the study. The storage of 'Bingo ${ }^{\text {PBR }}$ variety fruit in NA conditioned a 
slight decrease in AA, proved in the last time of the analyzes, but the storage in CA did not determine a similar trend.

Table 9. Changes of total phenolic content $\left[\mathrm{mg} \cdot 100 \mathrm{~g}^{-1} \mathrm{f} . \mathrm{w}.\right]$ measured in 'Ananasnaya' and 'Bingo'PBR minikiwi fruit in postharvest period.

\begin{tabular}{|c|c|c|c|c|c|}
\hline \multirow{2}{*}{ Variable } & \multicolumn{5}{|c|}{ Time of Storage (Days) } \\
\hline & 0 & 14 & 28 & 42 & 56 \\
\hline & \multicolumn{5}{|c|}{ Ananasnaya } \\
\hline $\mathrm{CA}^{1}$ & $85.2 \pm 9.7 \mathrm{~A} \mathrm{a}$ & $93.0 \pm 13.0 \mathrm{~A} \mathrm{a}$ & $100.0 \pm 22.1 \mathrm{~A} \mathrm{a}$ & $86.5 \pm 10.3^{\mathrm{A} \mathrm{a}}$ & $82.5 \pm 12.9 \mathrm{~A} \mathrm{a}$ \\
\hline NA & $85.2 \pm 9.7 \mathrm{~A} \mathrm{a}$ & $92.8 \pm 6.8^{\mathrm{A} \mathrm{a}}$ & $99.7 \pm 17.5^{\mathrm{A} \mathrm{a}}$ & $91.3 \pm 9.2^{\mathrm{A} \mathrm{a}}$ & $84.0 \pm 11.4^{\mathrm{A} \mathrm{a}}$ \\
\hline Hrv A & $82.8 \pm 7.5^{\mathrm{A} \mathrm{a}}$ & $95.8 \pm 10.0 \mathrm{~A} \mathrm{~b}$ & $107.0 \pm 11.1 \mathrm{Ab}$ & $92.0 \pm 4.5^{\mathrm{A} \mathrm{a}}$ & $85.6 \pm 13.9 \mathrm{~A} \mathrm{a}$ \\
\hline \multirow[t]{2}{*}{ Hrv B } & $87.6 \pm 11.0^{\mathrm{A} \mathrm{a}}$ & $90.0 \pm 10.0^{\mathrm{A} \mathrm{a}}$ & $92.1 \pm 16.2^{\mathrm{A} \mathrm{a}}$ & $85.9 \pm 12.8^{\mathrm{A} \mathrm{a}}$ & $80.9 \pm 9.7^{\mathrm{A} \mathrm{a}}$ \\
\hline & \multicolumn{5}{|c|}{ Bingo $^{\text {PBR }}$} \\
\hline CA & $90.8 \pm 23.0 \mathrm{~A} \mathrm{~b}$ & $82.7 \pm 4.3^{\mathrm{A} \mathrm{b}}$ & $72.5 \pm 5.0 \mathrm{~A} \mathrm{a}$ & $71.4 \pm 9.9 \mathrm{~A} \mathrm{a}$ & $61.9 \pm 4.1 \mathrm{~A} \mathrm{a}$ \\
\hline NA & $90.8 \pm 23.0 \mathrm{Ab}$ & $83.1 \pm 12.1 \mathrm{~A} \mathrm{~b}$ & $78.8 \pm 4.5^{\mathrm{A} \mathrm{a}}$ & $74.4 \pm 5.0^{\mathrm{A} \mathrm{a}}$ & $68.5 \pm 3.4^{\mathrm{A} \mathrm{a}}$ \\
\hline Hrv A & $87.0 \pm 7.5^{\mathrm{A} \mathrm{b}}$ & $81.6 \pm 10.3^{\mathrm{A} \mathrm{b}}$ & $74.1 \pm 2.9^{\mathrm{A} \mathrm{a}}$ & $73.8 \pm 7.7^{\mathrm{A} \mathrm{a}}$ & $64.7 \pm 4.2^{\mathrm{A} \mathrm{a}}$ \\
\hline Hrv B & $94.7 \pm 6.4^{\mathrm{A} \mathrm{b}}$ & $84.2 \pm 7.4^{\mathrm{A} \mathrm{b}}$ & $77.2 \pm 7.2 \mathrm{~A} \mathrm{~b}$ & $72.0 \pm 8.3^{\mathrm{A} \mathrm{a}}$ & $65.7 \pm 5.6^{\mathrm{A} \mathrm{a}}$ \\
\hline
\end{tabular}

${ }^{1}$ CA—controlled atmosphere; NA—normal atmosphere cold store; Hrv A—harvest A; Hrv B—harvest B; \pm —standard deviation; different superscript letters are assigned to statistically significant differences when comparing (capital letter): storage conditions (average for stage maturity) or harvest maturity (average for storage conditions) and (lower case): period of storage; the cultivars were not compared with each other.

Table 10. Changes of antioxidant activity [mg AAE· $100 \mathrm{~g}^{-1}$ f.w.] measured in 'Ananasnaya' and 'Bingo'PBR minikiwi fruit in postharvest period.

\begin{tabular}{|c|c|c|c|c|c|}
\hline \multirow{2}{*}{ Variable } & \multicolumn{5}{|c|}{ Time of Storage (Days) } \\
\hline & 0 & 14 & 28 & 42 & 56 \\
\hline & \multicolumn{5}{|c|}{ Ananasnaya } \\
\hline $\mathrm{CA}^{1}$ & $1.00 \pm 0.08^{\mathrm{A} \mathrm{ab}}$ & $1.04 \pm 0.03^{\mathrm{A} \mathrm{b}}$ & $1.07 \pm 0.04 \mathrm{~A} \mathrm{~b}$ & $1.02 \pm 0.05 \mathrm{~A} \mathrm{~b}$ & $0.91 \pm 0.10^{\mathrm{A} \mathrm{a}}$ \\
\hline NA & $1.00 \pm 0.08^{\mathrm{A} \mathrm{a}}$ & $1.03 \pm 0.05 \mathrm{~A} \mathrm{a}$ & $1.06 \pm 0.06^{\mathrm{A} \mathrm{a}}$ & $1.05 \pm 0.04 \mathrm{~A} \mathrm{a}$ & $0.99 \pm 0.07 \mathrm{~A} \mathrm{a}$ \\
\hline Hrv A & $1.01 \pm 0.07 \mathrm{~A} \mathrm{a}$ & $1.03 \pm 0.04 \mathrm{~A} \mathrm{a}$ & $1.04 \pm 0.06^{\mathrm{A} \mathrm{a}}$ & $1.05 \pm 0.04 \mathrm{~A} \mathrm{a}$ & $1.01 \pm 0.07 \mathrm{~B} \mathrm{a}$ \\
\hline Hrv B & $1.00 \pm 0.09 \mathrm{Ab}$ & $1.04 \pm 0.04 \mathrm{~A} \mathrm{~b}$ & $1.07 \pm 0.03 \mathrm{Ab}$ & $1.02 \pm 0.05 \mathrm{~A} \mathrm{~b}$ & $0.89 \pm 0.06^{\mathrm{A} \mathrm{a}}$ \\
\hline \multicolumn{6}{|c|}{ Bingo $^{\text {PBR }}$} \\
\hline $\mathrm{CA}$ & $0.96 \pm 0.08^{\mathrm{A} \mathrm{a}}$ & $1.01 \pm 0.05^{\mathrm{A} \mathrm{a}}$ & $1.05 \pm 0.06^{\mathrm{A} \mathrm{a}}$ & $0.98 \pm 0.14 \mathrm{~A} \mathrm{a}$ & $0.97 \pm 0.12^{\mathrm{B} \mathrm{a}}$ \\
\hline NA & $0.96 \pm 0.08 \mathrm{Aab}$ & $1.06 \pm 0.04^{\mathrm{A} \mathrm{b}}$ & $1.01 \pm 0.14 \mathrm{Ab}$ & $0.98 \pm 0.15^{\mathrm{Ab}}$ & $0.88 \pm 0.10 \mathrm{~A} \mathrm{a}$ \\
\hline Hrv A & $0.90 \pm 0.05^{\mathrm{A} \mathrm{ab}}$ & $1.00 \pm 0.03^{\mathrm{A} \mathrm{b}}$ & $0.96 \pm 0.11^{\mathrm{Ab}}$ & $0.84 \pm 0.08^{\mathrm{A} \mathrm{a}}$ & $0.85 \pm 0.06^{\mathrm{A} \mathrm{a}}$ \\
\hline Hrv B & $1.03 \pm 0.02^{\mathrm{B} \mathrm{ab}}$ & $1.07 \pm 0.04^{\mathrm{A} \mathrm{b}}$ & $1.10 \pm 0.06^{\mathrm{B} \mathrm{b}}$ & $1.11 \pm 0.03$ B b & $1.00 \pm 0.12^{\mathrm{B} \mathrm{a}}$ \\
\hline
\end{tabular}

\footnotetext{
${ }^{1}$ CA—controlled atmosphere; NA—normal atmosphere cold store; Hrv A—harvest A; Hrv B—harvest B; \pm -standard deviation; different superscript letters are assigned to statistically significant differences when comparing (capital letter): storage conditions (average for stage maturity) or harvest maturity (average for storage conditions) and (lower case): period of storage; the cultivars were not compared with each other.
}

\section{Discussion}

Firmness is a basic quality feature describing deformation resistance of fruit. At harvest, it was found that the fruit firmness of both cultivars significantly differed. The fruits of 'Ananasnaya' were characterized by firmness of approx. $50 \mathrm{~N}$, while that of the 'Bingo' ${ }^{\text {PBR }}$ cultivar was approx. $35 \mathrm{~N}$. 14 days after harvest a significant reduction in the FF was found, to an average level of 17.9 and $13.9 \mathrm{~N}$, for 'Ananasnaya' and 'Bingo'PBR respectively. The rapid loss of firmness in the initial period of storage was previously reported by Fisk et al. [19]. White et al. [18] found that the hardy kiwifruits quickly lose firmness in the cooling conditions, i.e., much faster than the other species of the genus Actinidia, while decline of the FF after 2 weeks of cold storage can be even more than $50 \%$ of the initial value. Also, in previous experiments [11,16], it has been found that FF decreases more rapidly during the first 2-3 weeks of storage than in the later period. The conditions of the CA used in the experiment had a positive impact on the firmness of minikiwi fruits. 
The 'Bingo' ${ }^{\text {PBR }}$ fruits were significantly firmer until the 56th day, and 'Ananasnaya' fruits until the 42nd day, if they were stored in CA, not in NA. Positive effects of $\mathrm{O}_{2}$ reducing concentration and increase of $\mathrm{CO}_{2}$ were observed in 'Hayward' cultivar (A. deliciosa) by Öz and Eris [33], who also stated that the beneficial effect of gases modification in the CA conditions depends on the storage temperature and occurs only at temperatures below $5{ }^{\circ} \mathrm{C}$. The softening of fruit tissue is the effect of polygalacturonase enzyme activity, which is responsible for the degradation of pectin, the main components of cell walls, in the middle lamella. The activity of the polygalacturonase enzyme depends on the ambient temperature and its maximum activity is present in the range of $30-50{ }^{\circ} \mathrm{C}$, and significantly reduces at high temperatures (above $60^{\circ} \mathrm{C}$ ) and low temperatures [34]. The experiment proved that not only storage conditions, but also state of physiological maturity of the fruits determines their firmness. Hardy kiwifruits of 'Ananasnaya' harvested when the content of the extract (SSC) was $7.6^{\circ}$ Brix were distinguished by a higher firmness up to 28 days and 42 days of storage for 'Bingo' ${ }^{\mathrm{PBR}}$. The results obtained indicate a slower softening of fruits harvested in the first period (harvest A). This opinion is shared by Fisk et al. [35] who found that the hardy kiwifruits soften slower if harvested at the SSC below $9^{\circ}$ Brix. In general, the fruits harvested at the SSC of $7.7^{\circ}$ Brix and stored under CA conditions were much firmer than in the other combinations.

The results obtained show that during storage there is an increase of SSC in hardy kiwifruits. It should be noted that the rapid increase in the SSC was observed after 14 days of storage. Faster starch hydrolysis to monosaccharaides and the related growth of extract content occurred in fruits stored in the NA than in CA. The 'Ananasnaya' fruits turned out to be "sweeter" because their maximum value of SSC after storage was $15.8^{\circ}$ Brix, while the 'Bingo'PBR_13.5 ${ }^{\circ}$ Brix. Also Park et al. [36] observed an increase in SSC during the storage of A. deliciosa fruits. The results obtained by Strik [27] show that the SSC in A. arguta fruits can get value of up to $25^{\circ}$ Brix, but neither in these studies nor in the works of Fisk et al. [19,35] such high values of SSC have been achieved. The SSC is associated with the activity of enzymes that cause degradation of starch and with the reduced level of monosaccharaides (hexoses) in the respiration process [37]. In the NA conditions respiration process takes place more dynamically, leading to the rapid consumption of substrates. The result of this process may be a lower SSC in 'Bingo' ${ }^{\text {PBR }}$ fruits stored in NA than in CA after 56 days, as observed in the experiment. Fruits of two cultivars derived from the harvest B, during the testing period were characterized by a higher value of this parameter. Presumably, this was associated with a longer period of berry ripening on the vine, and the related increase in the content of assimilates in the cells of the fruit. Abdala et al. [38] found that the state of kiwi fruit maturity at harvest does not condition the SSC or the TA after their storage. Just as in the reports of other authors $[28,35]$ their own studies confirm that TA decreases significantly during storage. Generally, higher TA was found in fruits of harvest $\mathrm{A}$ and stored in the CA chamber. Decrease in TA is associated with respiration occurring in fruits. Therefore, higher TA found in fruits stored in CA (after 42 and 56 days) was the result of slower ripening of the fruits caused by the reduced concentration of $\mathrm{O}_{2}$ and by $\mathrm{CO}_{2}$ increase.

The peel colour change is caused by the degradation of chlorophyll as the fruits ripen. The fruits of 'Ananasnaya' variety were characterized by a grass-green basic color of the peel, while the peel of 'Bingo' ${ }^{\text {PBR }}$ variety was definitely more green-yellow. During storage, the fruits lose their green colour, however, this process occurred faster in fruits stored in NA than in CA. In addition, during research, color intensity disappearance was found, which progressed more slowly in the fruit stored in a CA. Significant differences were found after 28 days of storage and on subsequent analysis days. The study has not reported the effect of harvest time on the intensity of green colour of fruit peel, as in the previous studies by Fisk et al. [19,35].

As a result of transpiration and a respiration process, the fruits lost after storage almost $2.5 \%$ of their initial mass. It is surprising that higher losses were recorded in fruits harvested in the first period of harvest (harvest A) than in the second (harvest B). The 
opposite results were obtained by Ghasemnezhad et al. [21] who stated that the fruits of A. deliciosa better preserved their mass if harvested at $6.5^{\circ}$ Brix than at a higher SSC. High mass loss of the harvest A can be associated with less amount wax covering fruit peel. The results obtained in the experiment are consistent with the results obtained by Fisk et al. [19] who claim that the storage in NA may even cause more than $3 \%$ mass loss of the hardy kiwifruits. However, Fisk et al. [19] in their studies did not evaluate effect of CA on the fruit mass loss.

Vitamin $C$ and polyphenols are the largest group of antioxidants known to consumers. The content of vitamin $C$ in fruits after harvest was similar to the results obtained by Nishiyama et al. [39], who reports that the AAC in fruits of $A$. arguta ranges within 37 to $185 \mathrm{mg} \cdot 100 \mathrm{~g}^{-1} \mathrm{f} . \mathrm{w}$. The vitamin $C$ content changed during storage. In general we can say that, regardless of storage conditions AAC in fruits increased up to 28th day, then decreased although not always significantly as far as statistics is concerned. The results obtained are consistent with the reports of Tavarini et al. [40], who reported decrease of AAC in fruits of 'Hayward' after storage in NA. The results of the studies show that fruits which ripen longer on the vine may contain higher amount of vitamin C. 'Bingo' ${ }^{\text {PBR }}$ fruits were characterized by a higher content of vitamin C if harvested at higher SSC, which was not observed in the 'Ananasnaya' fruits. Also Ghasemnezhad et al. [21] found a higher AAC after storage in fruits harvested at the SSC above $9.0^{\circ}$ Brix. TPC in fruits, like vitamin $\mathrm{C}$, affect their health prevention function. The TPC in fruits of both cultivars does not differ from those obtained in previous studies [6]. These values, however, are lower than in the reports of Kim et al. [17] or Fisk et al. [35]. The present studies do not prove the effect of storage conditions on the TPC. In general we can say that the TPC remained at a similar level ('Ananasnaya') or slightly decreased during storage ('Bingo'PBR). Yildirim and Bayir [25] present a similar point of view and state that the storage of fruit in CA promotes the inhibition of polyphenols loss. In contrast, Fisk et al. [35] observed an increase in the TPC in fruits of the 'Ananasnaya' stored at $2{ }^{\circ} \mathrm{C}$. In an independently performed experiment, an increase in the TPC was observed up to 28 th day of storage ('Ananasnaya'), however, it was not confirmed by statistics. The state of physiological ripeness of fruit at harvest did not determine the TPC. Only in the fruits of 'Ananasnaya' the increase in polyphenol content was observed after 14 and 28 days if the fruits originated from the first harvest, but in consecutive dates of analyses the TPC decreased. Ghasemnezhad et al. [21] state that $A$. deliciosa fruits, characterized by a low SSC during the harvest, contain more polyphenols after storage. Also Fisk et al. [35] are of the opinion that the hardy kiwifruits harvested at a lower SSC are characterized by a higher TPC.

The AA is a measure of the ability to scavenge free radicals. The analyses showed that the AA of fruits at harvest maturity is on average $1.0 \mathrm{mg}$ ascorbic acid. $\mathrm{g}^{-1} \mathrm{f} . \mathrm{w}$. The results of these studies confirm the studies by Latocha et al. [6] who reported that the AA of 'Ananasnaya' fruits was approx. $1.0 \mathrm{mg} \mathrm{AAC} \cdot \mathrm{g}^{-1} \mathrm{f} . \mathrm{w}$. An individually performed experiment did not prove a significant effect of storage conditions on AA, which is consistent with the reports of Yildirim and Bayir [25]. Individual findings indicate that the fruits of 'Bingo' ${ }^{\text {PBR }}$ harvested in the second term (harvest B) were characterized by higher AA. This relationship is statistically confirmed only in this cultivar, which may be associated with its hybrid origin conditioning the synthesis of anthocyanin dyes found in the peel of the fruit. The reports of other authors emphasize the fact that the AA is higher in less mature fruits [21].

\section{Conclusions}

The fruits of 'Bingo' ${ }^{\text {PBR }}$ harvested at SSC $9-10^{\circ}$ Brix are characterized by a higher content of soluble solids and lower acidity after storage then the fruits harvested at SSC $7-8^{\circ}$ Brix. A significant decrease in fruit firmness occurs during the first 14 days of storage. This process occurs extremely fast especially in the ordinary cold storage and in fruits harvested at the extract content above $9^{\circ}$ Brix. In conditions of controlled atmosphere fruits of 'Bingo' ${ }^{\text {PBR }}$ can be stored for even more than 8 weeks, provided that fruits are 
harvested at harvest maturity, i.e., at $7-8^{\circ}$ Brix. Low concentration of $\mathrm{O}_{2}$ in the $\mathrm{CA}$ results that the fruits look fresh for a longer time, are more firm, and have a greener peel colour. 'Bingo' ${ }^{\text {PBR }}$ fruits were characterized by a higher content of vitamin $C$ if harvested at higher soluble solids. During storage the vitamin C content decreases in 'Ananasnaya' fruits, but it was not found in 'Bingo' harvested at SSC 9-10 ${ }^{\circ}$ Brix. The polyphenol content during storage does not change or slightly decreases, reflecting the greater stability of polyphenols in fruits.

Author Contributions: Conceptualization, E.S., T.K. and E.Z.-J.; methodology, T.K.; formal analysis, E.S., T.K. and E.Z.-J.; investigation, E.S., T.K.; resources, E.S., T.K.; data curation, T.K.; writingoriginal draft preparation, E.S., T.K. and E.Z.-J.; writing-review and editing, E.S., T.K. and E.Z.-J.; supervision, T.K. All authors have read and agreed to the published version of the manuscript.

Funding: This research received no external funding.

Institutional Review Board Statement: Not applicable.

Informed Consent Statement: Not applicable.

Data Availability Statement: The data presented in this study are available on request from the corresponding author.

Conflicts of Interest: The authors declare no conflict of interest.

\section{References}

1. Williams, M.H.; Boyd, L.M.; McNeilage, M.A.; MacRae, E.A.; Ferguson, A.R.; Beatson, R.A.; Martin, P.J. Development and commercialization of 'Baby Kiwi' Actinidia arguta Planch. Acta Hortic. 2003, 610, 8-16. [CrossRef]

2. Bieniek, A.; Draganska, E.; Pranckietis, V. Assessment of climatic conditions for Actinidia argute cultivation in north-eastern Poland. Zemdirb. Agric. 2016, 103, 311-318. [CrossRef]

3. Latocha, P. Some morphological and biological features of 'Bingo'-A new hardy kiwifruit cultivar from Warsaw University of Life Sciences (WULS) in Poland. Rocz. Pol. Tow. Dendrol. 2012, 60, 61-67.

4. Gao, Z.; Deng, G.; Li, Y.; Huang, H.; Sun, X.; Shi, H.; Yao, X.; Gao, L.; Ju, Y.; Luo, M. Actinidia chinensis Planch prevents proliferation and migration of gastric cancer associated with apoptosis, ferroptosis activation and mesenchymal phenotype suppression. Biomed. Pharmacother. 2020, 126, 110092. [CrossRef] [PubMed]

5. Jiang, Z.E.; Zhong, Y.; Zheng, J.; Ali, M.; Liu, G.D.; Zheng, X.L. L-ascorbic acid metabolism in an ascorbate-rich kiwifruit (Actinidia. Eriantha Benth.) cv. White during postharvest. Plant. Physiol. Biochem. 2018, 124, 20-28. [CrossRef] [PubMed]

6. Latocha, P.; Krupa, T.; Wołosiak, R.; Worobiej, E.; Wilczak, J. Antioxidant activity and chemical difference in fruit of different Actinidia sp. Int. J. Food Sci. Nutr. 2010, 61, 381-394. [CrossRef]

7. Wojdyło, A.; Nowicka, P.; Oszmianski, J.; Golis, T. Phytochemical compounds and biological effects of Actinidia fruits. J. Funct. Foods 2017, 30, 194-202. [CrossRef]

8. Du, G.; Li, M.; Ma, F.; Liang, D. Antioxidant capacity and the relationship with polyphenol and Vitamin C in Actinidia fruits. Food Chem. 2009, 113, 557-562. [CrossRef]

9. Bieniek, A. Mineral composition of fruits of Actinidia arguta and Actinidia purpurea and some of their hybrid cultivars grown in northeastern Poland. Pol. J. Environ. Stud. 2012, 21, 1543-1550. Available online: http:/ /www.pjoes.com/Mineral-Compositionof-Fruits-of-Actinidia-Arguta-r-nand-Actinidia-Purpurea-and-Some,88901,0,2.html (accessed on 12 November 2020).

10. Cheah, L.H.; Irving, D.E. Kiwifruit. In Postharvest Physiology and Storage of Tropical and Subtropical Fruits; Mitra, S.K., Ed.; CAB International: New York, NY, USA, 1997; pp. 209-227.

11. Krupa, T.; Latocha, P.; Liwińska, A. Changes of physicochemical quality, phenolics and vitamin C content in hardy kiwifruit (Actinidia arguta and its hybrid) during storage. Sci. Hortic. 2011, 130, 410-417. [CrossRef]

12. Tabatabaekoloor, R. Effects of storage duration and conditions on some characteristics of kiwifruit cv. Hayward. Int. J. Agron. Plant. Prod. 2011, 2, 23-27. Available online: https:/ / scholar.google.pl/scholar?hl=pl\&as_sdt=1\%2C5\&as_vis=1\&q= Effects+of+storage+duration+and+conditions+on+some+characteristics+of+kiwifruit+cv.+Hayward.+International+Journal+ of + Agronomy+and+Plant+Production $+2011 \% 2 C+2 \% 281 \% 29 \% 2 C+23-27 . \& b t n G=($ accessed on 12 November 2020).

13. Öz, A.T.; Eris, A. Influence of harvest time maturity and storage condition on internal ethylene production rate of "Hayward" kiwifruits. J. Food Agric. Environ. 2010, 8, 185-187. [CrossRef]

14. Goffi, V.; Modesti, M.; Forniti, R.; Botondi, R. Quality of green (Actinidia chinensis var. deliciosa 'Hayward') and yellow (A. chinensis var. chinensis 'Soreli') kiwifruit during cold storage at $0{ }^{\circ} \mathrm{C}$ in normal atmosphere and with gaseous ozone. Acta Hortic. 2018, 1218, 473. [CrossRef]

15. Tomala, K.; Grzeda, M.; Guzek, D.; Głabska, D.; Gutkowska, K. The Effects of Preharvest 1-Methylcyclopropene (1-MCP) Treatment on the Fruit Quality Parameters of Cold-Stored 'Szampion' Cultivar Apples. Agriculture 2020, 10, 80. [CrossRef] 
16. Lim, S.; Han, S.H.; Kim, J.; Lee, H.J.; Lee, J.G.; Lee, E.J. Inhibition of hardy kiwifruit (Actinidia arguta) ripening by 1-methylcyclopropene during cold storage and anticancer properties of the fruit extract. Food Chem. 2016, 190, 150-157. [CrossRef] [PubMed]

17. Kim, H.O.; Hewett, E.W.; Lallu, N. The role of ethylene in kiwifruit softening. Acta Hortic. 1999, 498, 255-262. [CrossRef]

18. White, A.; de Nichal Salva, H.; Requeiro-Tapia, C.; Harker, F.R. Evaluation of softening characteristics of fruit from 14 species of Actinidia. Postharvest Biol. Technol. 2005, 35, 143-151. [CrossRef]

19. Fisk, C.L.; Silver, A.M.; Strik, B.C.; Zhao, Y. Postharvest quality of hardy kiwifruit (Actinidia arguta 'Ananasnaya') associated with packaging and storage conditions. Postharvest Biol. Technol. 2008, 47, 338-345. [CrossRef]

20. Giuggioli, N.R.; Briano, R.; Baudino, C.; Peano, C. Post-harvest warehouse management of Actinidia arguta fruits. Pol. J. Food Nutr. Sci. 2019, 69, 63-70. [CrossRef]

21. Ghasemnezhad, M.; Ghorbanalipour, R.; Shiri, M.A. Changes in physiological characteristics of kiwifruit harvested at different maturity stages after cold storage. Agric. Conspec. Sci. 2013, 78, 41-47. Available online: https://acs.agr.hr/acs/index.php/acs/ article/view / 794 (accessed on 12 November 2020).

22. Oh, S.B.; Muneer, S.; Kwack, Y.B.; Shin, M.H.; Kim, J.G. Characteristic of fruit development for optimal harvest date and postharvest storability in Skinny Green baby kiwifruit. Sci. Hort. 2017, 222, 57-61. [CrossRef]

23. Kucuker, E.; Ozturk, B.; Yildiz, K.; Ozkan, Y. Effect of aminoethoxyvinylglycine (avg) on the quality of japanese plum (Prunus salicina Lindell cv. 'Fortune') fruits. Acta Sci. Pol. Hortorum Cultus 2015, 14, 3-17. Available online: http://www.acta.media.pl/pl/action/ getfull.php?id=4539 (accessed on 12 November 2020).

24. Yin, X.R.; Allan, A.C.; Zhang, B.; Wu, R.M.; Burdon, J.; Wang, P.; Ferguson, I.B.; Chen, K.S. Ethylene-related genes show a differential response to low temperature during 'Hayward' kiwifruit ripening. Postharvest Biol. Technol. 2009, 52, 9-15. [CrossRef]

25. Yildirim, I.; Bayir, A. Effects of different storage techniques on the antioxidant capacity, total phenolics and flavonoids of 'Hayward' kiwifruit. Acta Hortic. 2013, 1012, 807-814. [CrossRef]

26. Strik, B.; Hummer, K. 'Ananasnaya' hardy kiwifruit. J. Am. Pomol. Soc. 2006, 60, 106-112.

27. Strik, B. Growing Kiwifruit; PNW Ext. Bull. 507; Oregon State University, Extension Service: Corvallis, OR, USA, 2005 ; pp. 21-23.

28. Latocha, P.; Krupa, T.; Jankowski, P.; Radzanowska, J. Changes in postharvest physicochemical and sensory characteristics of hardy kiwifruit (Actinidia arguta and its hybrid) after cold storage under normal versus controlled atmosphere. Postharvest Biol. Technol. 2014, 88, 21-33. [CrossRef]

29. PN-EN 12143. Soki Owocowe i Warzywne-Oznaczanie Zawartości Substancji Rozpuszczalnych Metoda Refraktometryczna; Polish Committee of Standardization: Warsaw, Poland, 2000. (In Polish)

30. PN-EN 12147. Soki Owocowe i warzywne-Oznaczanie kwasowości miareczkowej; Polish Committee of Standardization: Warsaw, Poland, 2000. (In Polish)

31. Singleton, V.L.; Orthofer, R.; Lamuela-Raventos, R.M. Analysis of total phenols and other oxidation substrates and antioxidants by means of Folin-Ciocalteu reagent. Methods Enzymol. 1999, 299, 152-158. [CrossRef]

32. De Gaulejac, S.C.; Provost, C.; Viras, N. Comparative study of polyphenol scavenging activities assessed by different methods. J. Agric. Food Chem. 1999, 47, 425-431. [CrossRef]

33. Öz, A.T.; Eris, A. The effects of CA (controlled atmosphere) and NA (normal atmosphere) storage on quality changes of differently harvested 'Hayward' (Actinidia deliciosa) kiwifruits. Gida J. Food 2009, 34, 83-89. Available online: https:/ / dergipark.org.tr/en/ $\mathrm{pub} /$ gida/issue/6845/91783 (accessed on 12 November 2020).

34. Li, S.; Liu, C.; Xin, G.; Zhang, B. Study on properties of PG separated and purified from Actinidia arguta. Adv. Mater. Res. 2014, 850-851, 1197-1201. [CrossRef]

35. Fisk, C.L.; McDaniel, M.R.; Strik, B.C.; Zhao, Y. Physicochemical, sensory, and nutritive qualities of hardy kiwifruit (Actinidia arguta 'Ananasnaya') as affected by harvest maturity and storage. J. Food Sci. 2006, 71, 204-210. [CrossRef]

36. Park, Y.S.; Jung, S.T.; Kang, S.G.; Drzewiecki, J.; Namiesnik, J.; Haruenkit, R.; Barasch, D.; Trakhtenberg, S.; Gorinstein, S. In vitro studies of polyphenols, antioxidants and other dietary indices in kiwifruit (Actinidia deliciosa). Int. J. Food Sci. Nutr. 2006, 57, 107-122. [CrossRef]

37. MacRae, E.; Quick, W.P.; Benker, C.; Stitt, M. Carbohydrate metabolism during postharvest ripening in kiwifruit. Planta 1992, 188, 314-323. [CrossRef]

38. Abdala, A.; Gerasopoulos, D.; Stavroulakis, G. Effects of harvest maturity and storage on ripening and membrane permeability of Hayward kiwifruit. Adv. Horticult. Sci. 1996, 1, 3-7. Available online: https:/ / www.jstor.org/stable/42881483 (accessed on 12 November 2020).

39. Nishiyama, I.; Yamashita, Y.; Yamanaka, M.; Shimohashi, A.; Fukuda, T.; Oota, T. Varietal difference in vitamin C content in the fruit of kiwifruit and other Actnidia species. J. Agric. Food Chem. 2004, 52, 5472-5475. [CrossRef]

40. Tavarini, S.; Degl'Innocenti, E.; Remorini, D.; Massai, R.; Guidi, L. Antioxidant capacity, ascorbic acid, total phenols and carotenoids changes during harvest and after storage of Hayward kiwifruit. Food Chem. 2008, 107, 282-288. [CrossRef] 